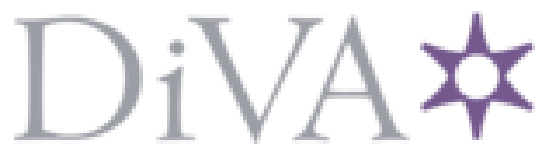

http://www.diva-portal.org

This is the published version of a paper published in Journal of social archaeology.

Citation for the original published paper (version of record):

Bolin, A., Nkusi, D. (2022)

Rwandan solutions to Rwandan problems: Heritage decolonization and community engagement in Nyanza District, Rwanda

Journal of social archaeology, 22(1): 3-25

https://doi.org/10.1177/14696053211053974

Access to the published version may require subscription.

N.B. When citing this work, cite the original published paper.

Permanent link to this version:

http://urn.kb.se/resolve?urn=urn:nbn:se:Inu:diva-108745 


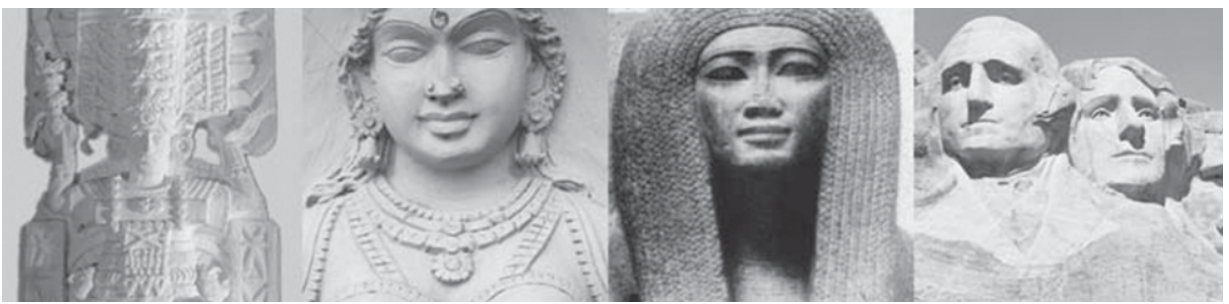

\title{
Rwandan solutions to Rwandan problems: Heritage decolonization and community engagement in Nyanza District, Rwanda
}

Journal of Social Archaeology 202I, Vol. 0(0) I-23

(C) The Author(s) 202I

\section{(c) (i)}

Article reuse guidelines:

sagepub.com/journals-permissions DOI: $10.1177 / 14696053211053974$ journals.sagepub.com/home/jsa

@SAGE

\section{Annalisa Bolin}

UNESCO Chair on Heritage Futures, Department of Cultural Sciences, Linnaeus University, Sweden

\section{David Nkusi}

Rwanda Cultural Heritage Academy, Rwanda

\begin{abstract}
Highlighting the rural district of Nyanza in Rwanda, this article examines community relations to heritage resources. It investigates the possibilities for more ethical, engaged models of heritage management which can better deliver on agendas of decolonization and development. Our research finds that Nyanza's heritage stakeholders highly value heritage's social and economic roles, but communities are also significantly alienated from heritage resources. In seeking to bridge this gap, heritage professionals utilize a discourse of technocratic improvement, but community leaders emphasize ideas of ownership, drawing on higher state-level discourses of self-reliance and "homegrown solutions." They mobilize the state's own attempts to filter developing, decolonizing initiatives through Rwandan frameworks to advocate for communities' right to participate in heritage. This local agency offers a roadmap for utilizing favorable aspects of existing governance to push heritage management toward community engagement and decolonization.
\end{abstract}




\author{
Keywords \\ Communities, heritage management, decolonization, development, Rwanda
}

\title{
Introduction
}

The importance of communities to heritage management and archaeology is increasingly recognized in scholarship and practice (Atalay, 2012; Colwell and Ferguson, 2008; Chitty, 2017; Higgins and Douglas, 2020; Kyriakidis, 2019). Engaging communities in heritage management is part of a more ethically responsive and socially responsible heritage practice (Colwell and Joy, 2015) and has also been framed as an issue of human rights (Meskell, 2010; Thiaw and Ly, 2020). Such attempts aim to ensure that those who are most connected to heritage, by virtue of history, proximity, cultural ties, or other factors, benefit from its use in social and/or economic terms. In Africa, colonialism's alienation of communities from their own heritage and the push for development additionally complicate these efforts (Baillie and Sørensen, 2021a; Schmidt and Pikirayi, 2016), which are not only a mode of technical improvement but also an attempt to decolonize heritage.

Highlighting Rwanda, this article examines how communities relate to heritage resources and their management, along with the possibilities for community engagement and new management models which can better deliver on agendas of development and decolonization. Focusing on stakeholders in the heritage sector and leaders of local communities, we trace the prevailing understandings of heritage in Nyanza District, a rural area referred to as a cultural and historical hub (igicumbi cy'umисо n'amateka) largely due to its connections with Rwanda's royal history. We find that those interviewed highly value heritage's social and economic roles, but simultaneously, communities are significantly alienated from heritage resources. While this may derive from colonial heritage management models, it has also been exacerbated by current models of heritage governance. In seeking to bridge this gap, our interviewees utilize two parallel discourses: one of technocratic improvement focused on decentralization and technical responses, and the other of ownership, grounded in ideas of self-reliance and "homegrown solutions." This concept of ownership reflects higher-level state discourses, which local community leaders draw upon to call for increased community involvement in heritage management. These leaders mobilize the state's own attempts to filter development and decolonization through Rwandan contexts and capabilities in order to advocate for communities' right to participate in heritage. This suggests that local ideation is a rich source of solutions, capable of aligning community needs with favorable national discourses (those of self-reliance and homegrown solutions, in this case) in order to create levers for instituting decolonial and/or community-based heritage management.

In the next section, we examine scholarship on the intersections of heritage management, decolonization, and development in sub-Saharan Africa, followed by a discussion of the heritage sector in Rwanda. We then proceed to the Nyanza District case study, whose findings are analyzed in the context of broader Rwandan governing orientations, and conclude with a discussion of the opportunities this presents for 
transforming the practice of heritage management in the district or even, potentially, in Rwanda as a whole.

\section{Heritage, decolonization, and development in Africa}

In much of the sub-Saharan African region, heritage management and archaeology as we know them today were instituted by colonial regimes (Chirikure et al., 2017). Heritage was excavated, interpreted, and controlled by colonial elites and by people trained and educated in colonial systems; traditional custodians, who had managed and preserved notable material heritage, were pushed aside from many of these sites, while a monumentalist approach to heritage was instituted (Jopela, 2011). Evangelism and the socalled civilizing mission also sought to separate colonized Africans from their traditional culture. In many parts of the region, management systems previously organized by colonizers have retained their power even since independence. Management decisions may still proceed along these top-down colonial lines, ultimately reinforcing the exclusion of local communities from heritage (Chirikure et al., 2010; Chirikure et al., 2017; Ndoro and Wijesuriya, 2015). Such management systems focus on protecting heritage from people, rather than managing it with, by, or for them (Atalay, 2012).

However, there have been challenges and changes to this colonial legacy in heritage management. African critiques of Western-style museums and heritage structures have argued that a new, decolonized model for heritage management can and should be created (Chirikure, 2021; Keitumetse, 2016; Ndoro et al., 2017; Schmidt and Pikirayi, 2016). Such scholars join a growing chorus of researchers who are engaging with the questions of decolonization in heritage, archaeology, and museums around the world (e.g., Atalay, 2006; Giblin, 2012; Hicks, 2020). African scholars have particularly noted that it is critical to develop African modes of responding to heritage challenges, rather than adopting present-day Western models of management wholesale. For example, Jopela (2011) calls for a revitalization of African traditional custodianship based on customary rules and laws while holistically integrating nature and culture. At the same time, neither is a radical excision of Western-style heritage legacies required, according to others: "What does not work is a strategy that flows from an 'anything-goes-as-long-as-it-islocal' or an 'anything-does-not-go-as-long-as-it-is-Western' approach" (Chirikure et al., 2017: 2). Instead, they call for an informed process of selection which is responsive to local conditions, or what Baillie and Sørensen (2021b, 3) label a "local tailor-made response."

Engagement with communities, ensuring that management takes into account local contexts, needs, and dynamics, is one mode for pursuing this responsivity in heritage management. Some methods attempt to bring communities into conservation efforts (Chitty, 2017); to transfer control over heritage to communities through participatory methods and Indigenous archaeologies (Atalay, 2012; Colwell and Ferguson, 2008); and to use heritage to empower those who are marginalized by national and official heritage frameworks (Kyriakidis, 2019). These efforts are not limited to post-colonial situationsthere are numerous examples in the Global North outside Indigenous contexts, for example (e.g., Simpson, 2008)_but may be particularly pressing in the Global South. 
Chirikure et al., (2017) argue that enabling communities to engage with and manage their heritage is, in and of itself, a mode of decolonization. Such efforts counter colonial legacies of alienation from heritage and critically engage with the top-down governing structures inherited from colonialism that still shape heritage management in many African countries. Attention to communities is promising in terms of responding to the imperative to decolonize. However, it must be noted, as others have pointed out (Joseph, 2002), that simple attention to community is not a panacea for oppression. Even as local communities are often found at the bottom rung of power in heritage management, communities themselves can also reproduce forms of hierarchy and discrimination that exist along multiple axes in broader society. This cautions us to remember that turning to communities does not at a single stroke solve problems of inequality and inequity in heritage practice.

A simultaneous challenge for heritage management in Africa is the pursuit of economic development in this rapidly growing and urbanizing region (Baillie and Sørensen, 2021a; Giblin et al., 2011; Lane, 2011). Some nations have found heritage development, especially using heritage resources for tourism, to be a promising route (Makuvaza, 2014). Within heritage scholarship, researchers have outlined ways to integrate heritage with such development (Gould, 2018; Gould and Pyburn, 2017) and to circumvent what has sometimes been cast as an inherent opposition between the two (Ndlovu, 2017). Still, integration is challenging. Development, from using heritage sites for tourism to the associated infrastructure creation, can easily threaten the preservation of heritage resources (Comer, 2012); alienate communities from their heritage through commodification (Herrera, 2014) while eliminating their capability to utilize it in a culturally meaningful way (Chirikure et al., 2010); and arrogate control over heritage to governments, multinational organizations, and experts (Lafrenz Samuels, 2010), while benefits drain away from local communities. Such challenges of community engagement are simultaneously ethically and practically problematic, especially given that it is wellestablished that alienated communities can also imperil the survival of heritage resources (Brosius et al., 2005). On the other hand, however, communities that are engaged with and benefit from heritage, including economically, are more likely to protect and ensure the survival of heritage resources that they value.

Moreover, heritage development is also framed by larger economic forces. In Africa, histories of colonial exploitation and underdevelopment have led to dependence on international aid (Rodney, 2018). Domestic economic development leading to aid independence, then, is understood by some governments of the region, including Rwanda's, to constitute a decolonizing effort in that it aims to reduce dependence on other countries and susceptibility to neocolonial influences (Beloff, 2020: 10-11; Mann and Berry, 2015). In this context, by helping to pursue such independence through development, heritage's contribution to decolonization — on a national scale — can also be economic.

\section{Rwanda's heritage sector}

Rwanda's global image is dominated by the history of the 1994 Genocide Against the Tutsi, but the country possesses a rich and extensive cultural heritage. Much of this 
heritage is intangible; one example is centuries of oral histories (Byanafashe and Rutayisire, 2016: 8-13; Giblin, 2018), such as imivugo poems transmitted to successive generations by highly valued abasizi poets. In terms of tangible heritage, two aspects are better-studied academically than others in Rwanda: natural heritage and Genocide memorialization (Giblin et al., 2011: 176). The national parks, with their famed mountain gorillas, take pride of place in the government's tourism strategy, while the Genocide memorials are both well-known and well-studied. Cultural heritage sites are less highlighted in both scholarship and in management. Indeed, when cultural and natural heritage come into conflict, for example, in questions of tourism and preservation, natural heritage tends to emerge victorious (Giblin et al., 2017), and cultural heritage has "long been regarded as being a sector of minor importance" (Ministry of Sports and Culture, 2008: 12). However, Rwanda does not lack cultural heritage sites, including cultural landscapes. Some 500 are known, at least 300 inventoried by government institutions, and over 100 documented in a volume (currently in preparation) by Rwanda Cultural Heritage Academy (RCHA).

The entities mainly responsible for heritage management in Rwanda are state-led. In part, this reflects the country's generally high governing capacity-Rwanda has been called a "developmental state," characterized by strong state direction (Hasselskog, 2018; Mann and Berry, 2015). It also indicates the value of heritage to the post-Genocide nation, where heritage is meant to help stabilize and unify the country after conflict, and so government involvement is high (Bolin, 2019a). Organizations involved in heritage management in Rwanda include institutions directed by the central government, such as Rwanda Cultural Heritage Academy (RCHA), which is partly constituted of the former Institute of National Museums of Rwanda (INMR). Entities at lower governing levels are also involved, such as district governments, which are responsible for handling lowerprofile heritage resources. Despite state dominance in the heritage sector, there is also an increasing integration of non-state actors into the area of cultural tourism. These include organizations along the lines of Nyanza District's community-based tourism enterprises (CBTEs).

These institutions govern a heritage management system shaped by colonial intervention. When heritage management in Rwanda became codified in the legal system, it was under a Belgian colonial-era decree (Government of Rwanda, 1939). This law focused on the protection of material heritage - especially built heritage, archaeological sites, and artifacts - of "historic, prehistoric, archaeological, ethnographic, or artistic" interest, and assigned control over its listing and protection to the Governor General. The colonial regime had other impacts on heritage as well. As in many nations of the region, Rwanda's museum sector began with the facilitation and participation of the former colonizer in founding the National Museum of Rwanda and other institutions (De Becker, 2016; Giblin, 2018).

In recent years, however, there have been deliberate efforts to decolonize the heritage landscape. For example, the Ethnographic Museum's exhibitions have been recast in order to eliminate colonial framings regarding aspects of Rwandan life such as ethnicity (De Becker, 2016). Other initiatives of decolonization include attempts to transform museum exhibitions and revitalize cultural heritage through training and outreach, as well 
as rethinking conservation practices (Umuhoza, 2021). There have also been changes to legal instruments. In 2016, the Belgian-era statute was replaced by a new law which maintained a focus on heritage listing while incorporating more categories of heritage, including tangible and intangible, as well as particular provisions for folklore and traditional knowledge (Government of Rwanda, 2016). This law, in addition to the National Culture Heritage Policy created in 2008 and renewed in 2015, takes an "inclusive" attitude toward heritage, emphasizing the importance not only of tangible but also intangible heritage; the Policy further highlights the importance of heritage to achieving development goals (Giblin, 2018; Ministry of Sports and Culture, 2015). The heritage sector anticipates that, when fully enacted, the law will both protect sites and increasingly involve local communities in heritage inventories and preservation (M. Mugabowagahunde, pers. comm., 2021).

In the domestic political context, heritage's aspirational uses focus on creating peace and social cohesion, which echoes priorities put forward by groups such as the Council of Europe and UNESCO (Giblin, 2013: 5-6; The Council of Europe, 2013). Heritage is integral to the effort to build a "New Rwandan" identity through recourse to heritage, that is, through mobilizing pre-colonial heritage to establish a unified national identity (Bolin, 2019a). This aims to replace the ethnic fragmentation instantiated by colonial governance, which ultimately provided a roadmap for genocide. As such, heritage plays a role in healing the post-conflict society (Giblin, 2013) and pursuing national reconciliation, along with promoting pride in Rwandanness (De Becker, 2016). It is further utilized by the government to create coherent narratives of the past, including about the Genocide Against the Tutsi in 1994 (Bolin, 2019b; Jessee, 2017).

Heritage is also mobilized within an economic agenda that relies on income from foreign sources. So, when used for tourism, heritage is often international-facing, despite a recent proliferation of initiatives encouraging domestic tourism (Gitera, 2008). Tourism itself has been identified as a priority area for future development (Ministry of Finance and Economic Planning, 2017: 44). Historically, Rwanda's tourism sector has long been dominated by natural heritage. However, under Vision 2050 (a document guiding governing priorities for the next 30 years after Vision 2020), tourism offerings are poised to diversify (Gatete, 2016). As a result, cultural heritage is set to achieve a more prominent role in the tourism development landscape: cultural tourism is "one of the pillars of the National Cultural Heritage Policy with great potential for national economic development" (Ministry of Sports and Culture, 2016: 3).

The relationship of the Rwandan heritage sector, especially that which is governed by the state, to communities is mixed. Various outreach and education programs exist, such as those operated by INMR (now RCHA), but the heritage sector has not yet pursued more fully collaborative or participatory models of cultural heritage management such as those promoted by heritage scholars (Atalay, 2012; Colwell and Ferguson, 2008). In Rwanda's natural heritage sector, the picture is slightly different. While local communities have been excluded from the national parks for reasons of preservation and tourism, impacting on their livelihoods and traditional ways of life, revenue-sharing programs attempt to counteract these conflicts by bringing development's benefits to those most affected 
(Kamuzinzi et al., 2015; Munanura et al., 2016). The relationship between the cultural heritage sector and communities is more fully explored in the case study below.

\section{Communities and heritage management in Nyanza District}

\section{Methodology}

Research for this article was carried out in fall 2020. ${ }^{1}$ Due to the COVID-19 pandemic, the authors collaborated remotely. We co-designed the project, questionnaires, and interview guides; Nkusi then conducted in-person interviews in Kinyarwanda and English (and in accordance with Rwanda's public health guidelines) in Nyanza District and administered questionnaires to literate, English-speaking participants. Interviews and questionnaires covered several themes, tailored to respondent profiles. These included the interviewee's definition of heritage and the value or importance they ascribed or did not ascribe to it; the relationship between their community or organization and heritage resources, and the impact of heritage management practices; definitions of development and its relationship with heritage; and visions of the future of heritage, its management, and development, with special attention to community relations. Interviews were recorded and questionnaires were answered in writing.

Interviewees $(n=48)$ were selected via the snowball method, drawing upon Nkusi's knowledge of and long-term embedding in the Nyanza heritage management landscape as an employee of RCHA who has undertaken numerous projects in the district. Participants included: Nyanza District authorities $(n=3)$; heritage professionals (such as an archaeologist, a curator, an outreach officer, and a cultural tourism development officer) ( $n=$ $10)$; directors of CBTEs $(n=2)$; museum professionals (managers of RCHA museums) $(n=9)$; expert consultants who have worked in Nyanza on heritage projects $(n=4)$; and local authorities $(n=20)$. This group of participants offered a cross-section of the key stakeholders in Nyanza's heritage field.

The "local authorities" category should be discussed in greater detail. Rwanda is divided into provinces, and within provinces, districts (e.g., Nyanza); below the district, the next level is the sector, and within the sector, the cell. Each cell consists of villages (imidugudu), the most finely-grained level of governance (see Chemouni, 2014). The local authorities consulted in this research are leaders representing 15-20 households within villages. Such leaders, known as mutwarasibo, are chosen as respected people of integrity by the community; they live in their community and are empowered to speak on its behalf. As a result, we view these leaders as valid proxies for communities in our research, but this does carry limitations, which are described further in the discussion section.

\section{Nyanza District and its heritage landscape}

Nyanza District is located in Rwanda's Southern Province. Its main city, also named Nyanza, is located along the highway that leads from the Rwandan capital, Kigali, to the Burundian capital, Bujumbura. The population density in Nyanza District, as in most of 


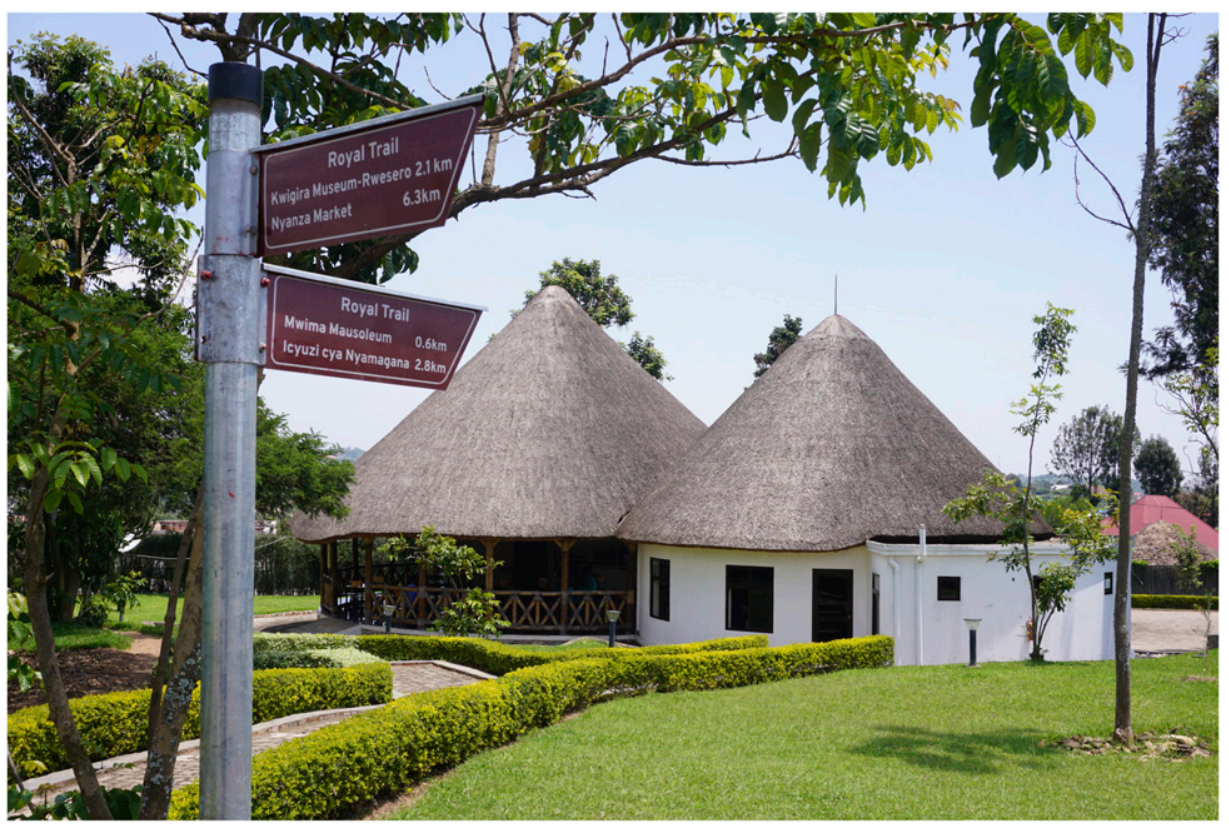

Figure I. Trail signage at the Kings' Palace Museum, Nyanza. Photo used with permission of GIZI Martin Karenzi.

Rwanda, is high, with over 320,000 people living in 672 sq. $\mathrm{km}^{2}$ In the district, like in the rest of Rwanda, the majority of the population is young (under 40); approximately half of the population is categorized by the national government as poor or extremely poor, ranking it about in the middle of all districts (National Institute of Statistics of Rwanda, $2012) .^{3}$ The primary form of employment, occupying over $80 \%$ of the population, is farming, with only $6 \%$ earning a wage from non-farm businesses (National Institute of Statistics of Rwanda, 2012). This is also in line with general conditions in Rwanda, which despite the government's efforts to develop an information and services economy remains a largely agricultural country. On the whole, conditions in Nyanza are not out of line with the national (non-Kigali) norm in terms of development and employment, but this leaves its population still highly dependent on subsistence agriculture and experiencing significant levels of poverty.

There are numerous recognized heritage resources in the district. These include two public museums administered by RCHA: the Kings' Palace Museum (Rukari; Figure 1), which focuses on the pre-colonial and early colonial monarchy and features replicas of traditional houses from King Musinga's royal residence, and the Kwigira Museum (Rwesero), highlighting Rwanda's history and "homegrown solutions" to Rwandan challenges. These and another private museum, the Rwanda African Art Museum, are located in and near Nyanza city. Rwanda Cultural Heritage Academy also manages a mausoleum on Mwima Hill, the burial site of three members of the Rwandan monarchy. 


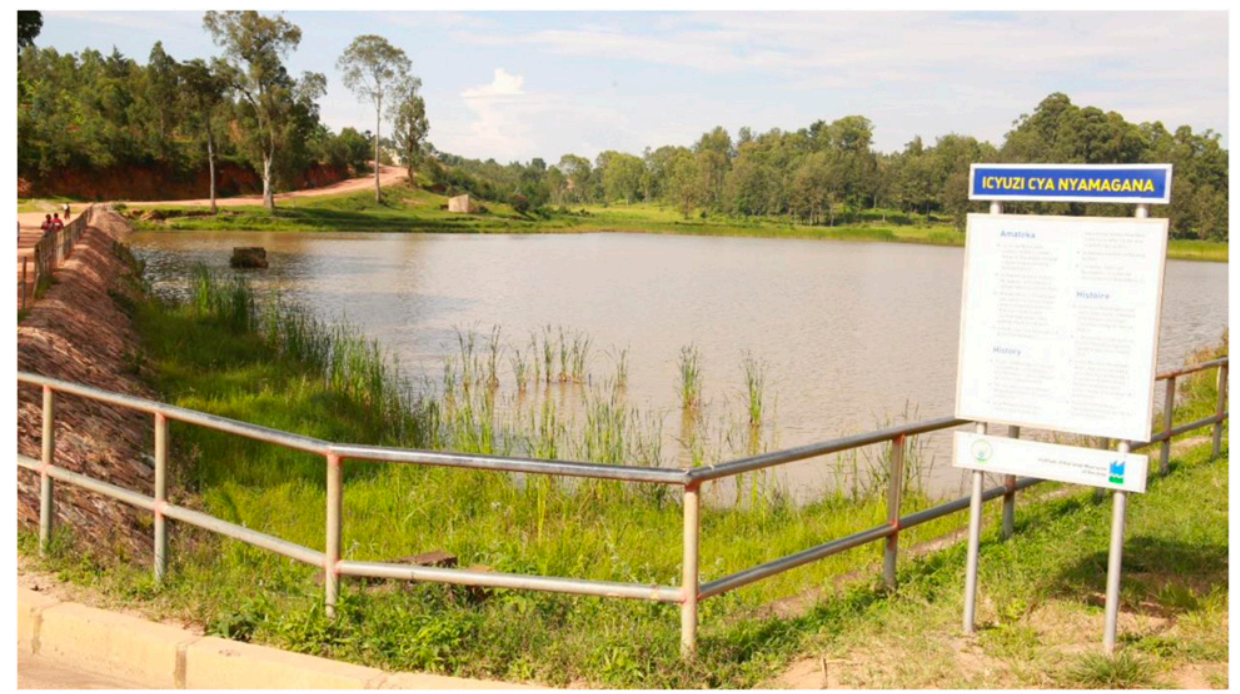

Figure 2. Icyuzi cya Nyamagana, a dam site constructed by King Mutara III Rudahigwa with the help of Dubois, a Belgian agricultural officer, following a severe famine in 1943-44. The intent was to counter malnutrition through fish farming. Photo used with permission of RCHA/Jean Paul Mugwaneza.

Although by law heritage sites are under the control of RCHA at the national level (Genocide-related sites are handled by the National Commission for the Fight Against Genocide), in terms of day-to-day management, other institutions are also involved. The Ministry of Agriculture and Animal Resources (MINAGRI) is responsible for certain sites associated with farming in the district. These include Mututu, a cattle farm constructed as a model by then-King Mutara III Rudahigwa in the late 1940s, and Ku Bigega, food stores constructed by the same king around the same time in response to, and against a recurrence of, the famine of 1943-44 (known as Ruzagayura). Nyanza District manages the associated wells, Amariba ya Mutende, and the dam site of Icyuzi cya Nyamagana (Figure 2). Near to Nyanza's city center is located the former palace site Mu Gakenyeri kwa Musinga, dating to 1899, of King Yuhi IV Musinga and Queen Mother Nyirayuhi IV Kanjogera — who were in power at the advent of colonization, when German explorers arrived (Des Forges, 2011). The number of sites associated with former rulers in Nyanza District is indicative of the area's historical role as the seat of the monarchy since 1899, the kingdom's first permanent capital, even as it had been repeatedly used as a temporary capital in prior years (Ishizawa and Karangwa, 2021). Christ-Roi Church, built by Belgian missionaries in 1935 on the location of King Musinga's residence, was the site of King Mutara III Rudahigwa's baptism in 1943; today, it is managed by the Catholic Church. Certain forests with historical and cultural value, such as Kibirizi, are managed by Rwanda Environment Management Authority. Three hiking trails of between eight and $15 \mathrm{~km}$ - the Royal Trail, Big-View Trail, and Gatagara Trail - cross the agricultural landscape to connect various of these cultural sites with natural heritage such as Remera Hill (Figure 3). 


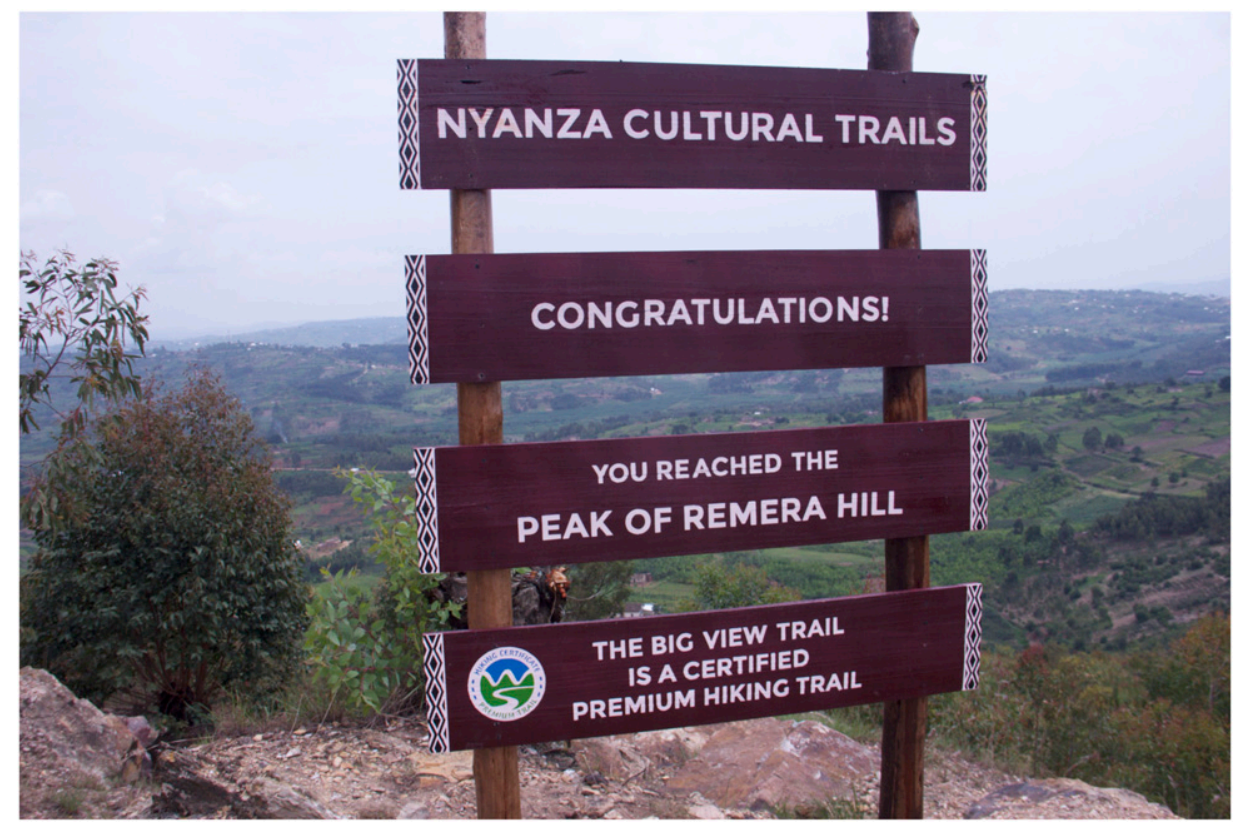

Figure 3. Nyanza Cultural Trails signage at the peak of Remera Hill. Photo used with permission of GIZ/Martin Karenzi.

Both domestic and international aspects of heritage are visible in Nyanza District. That is, in their historical and political significance, these sites aim to connect Rwandan audiences with their (particularly pre-colonial) past. As described in the previous section, the ultimate goal of such efforts is to contribute to knowledge about and pride in the past for Rwandans themselves. Additionally, resources such as the hiking trails are oriented toward domestic and international visitors as well as sporting associations in order to augment tourism revenue and job creation in the local area. Businesses such as CBTEs cater to hikers and other tourists. Nyanza is also the center of the Southern Heritage Corridor, a project spearheaded by Rwanda Development Board (RDB), which links multiple sites in Southern Province for heritage promotion and tourism. As such, the Nyanza heritage landscape is consistent with the social and economic priorities of the heritage sector nationally.

\section{Findings}

Heritage plays important social roles. The first key finding from our research is that heritage is understood to be socially valuable. Interviewees believe that heritage plays an important role in establishing identity: "Heritage is very important because it makes us who we are. It tells us where we have come from, where we are now and where we will be in the future." 4 For some, the construction of identity through heritage was inherently about 
pride, where knowledge of the past would lead to pride in that past. Some went so far as to indicate that heritage should be defined as that which is "good" in the past - a selective legacy - although others suggested that "good" and "bad" heritage are both heritage, with the key factor being how they are managed and the lessons drawn from them. Additionally, several interviewees highlighted the role of heritage in producing social cohesion, connecting people with a "sense of belonging to a wider community" and a "strong bond to the story behind the heritage." 6

In the Rwandan context, these aspects are implicitly related to recent histories of ethnic violence. One of the ways the government mobilizes heritage today is to bind people together within an identity drawn from a pre-colonial, pre-ethnic past. Such social cohesion through heritage, under the umbrella of an overarching Rwandan identity rather than Hutu, Tutsi, or Twa, is intended to help prevent the recurrence of violence along ethnic lines. ${ }^{7}$ One interlocutor stated a belief that "Genocide happened because of this low level of engagement in ... heritage. Heritage brings people together regardless [of] one's ethnic background." 8 This statement reflects the importance of a cohesive and inclusive Rwandan identity inherited from the past, and the role of the fracturing of this identity in enabling intergroup violence. Where the country has been wracked by violent histories, heritage is understood to offer an opportunity to restore not only social cohesion but also pride in a Rwandan identity, derived from the past, that is not defined by violent destruction. As a result, then, heritage production is not viewed as a luxury but rather as an important priority, an educational necessity, and even a requirement for building an enduring peace.

Heritage is useful for development-but this is a tricky line to walk. Many interlocutors additionally drew out the possibility for heritage to produce meaningful material benefits if used as a "generator for sustainable development." 9 They highlighted the potential of heritage to produce revenues that could raise local standards of living and improve "economic wellbeing." 10 This was understood as deriving from tourism: "Now as a country grows up in the way of development, those ... sites are now valorized and some of them were starting to be visited. Which means they now make money."11 Such visits can include both domestic and international tourism.

Despite the widespread belief among our interviewees that heritage could meaningfully be mobilized within the pursuit of development, however, some interlocutors expressed concern at the effect that this could have on heritage. One was particularly eloquent on this point:

To me, development is anti-heritage. Heritage is being washed away through urbanization; for example, plans are underway to bring down old buildings in Nyanza District and set up new buildings - something that will kill the authenticity of Nyanza as a cultural city. ... Some of our heritage sites are too modernized; for example, Mwima Mausoleum where two kings and [a] queen are laid to rest. I think we needed to see a more traditional sendoff of our kings. ${ }^{12}$

Interviewees who highlighted the need to preserve heritage in order to be able to mobilize it within development attempted to reconcile these positions. "The best use of 
the heritage is to maintain it authentically by avoiding any modifications," said a heritage development consultant: "Many tend to prettify the heritage for different reasons and that's totally wrong. ... [H] eritage can benefit people without transforming it but rather sustainably maintaining it with its originality/authenticity." This same interviewee, however, harped on the importance of heritage in achieving development goals through attracting tourists. In this perspective, it was precisely the preservation of heritage in a state of "authenticity" so as to maintain its appeal to visitors which would enable it to contribute to development.

At the same time, heritage was also seen as the source of potential solutions for this conflict. "Development should source its guided steps and information from heritage since heritage is like [a] data bank of history and cultural ideas,"13 one interviewee suggested. Another concurred, arguing that "Development should value and rely on heritage for its sustainability. Countries that had based their development process on their heritage/culture and history are the most developed today." 14 As will be discussed further below, this perspective utilizes the framework of drawing on the past as a resource for developing solutions to shape the future.

Community-heritage relations are disrupted. Interlocutors broadly agreed that, despite the importance of heritage to both social cohesion and economic development, there is a rift between communities in Nyanza District and the heritage which is supposed to be mobilized for these ends, imperiling communities' receipt of such benefits. Although some respondents believed that "heritage management is working well because even locals now understand the importance of protecting our heritage," 15 others strongly differed. One museum professional stated baldly that "there is no such relation" between communities and heritage sites. There are "no proper management systems" of heritage sites, said a CBTE director, with which the manager of a museum concurred, stating that Rwanda's current heritage management practices are "poor." This situation means that "without the component of [the] local community, [the development potential of heritage is] zero"; ${ }^{16}$ the same could presumably be said for heritage's role in building social cohesion.

Some identified this disjuncture as originating in the technical processes of heritage management. "The community feel neglected/isolated in the planning process in managing heritage. [They have] no sense of belonging," said one CBTE director. Another concurred that "we need to engage local people as much as possible. Not planning things in [the] office," a position that likely reflected CBTEs' mission of focusing on communities. One museum professional argued that heritage management is "not [working well] due to lack of professionals and funds"; a second suggested that it was "on the right track" but needed more investment in implementation, especially through putting in place and carrying out policies on topics such as conservation and conflict management. The exclusion of stakeholders from the "whole development value chain"17 was also singled out. These examples, found across most classes of interlocutors, highlight technocratic capacity, discussed further below.

Local community leaders were sweeping in their condemnation of the current heritage management system. Leaders indicated that communities' engagement in heritage is low, 
and that they feel excluded from the processes and outcomes of heritage management. "Heritage resources do not benefit us the way they should, be it at individual or collective level," they stated. The source of this failure was identified as being located in management practices. "We do not need to see results, we need to be part of the results," they argued. "We need to be part of the planning and development processes from start to end. The more we get pushed aside, the more we lose the value of these heritage resources." This pushing aside has had concrete effects on communities and, eventually, on heritage resources themselves: "We see them as [the] same as government projects that do not concern us. [And so we give] less care to these rich resources that surround us."

Solutions: Technocratic capacity versus ownership. Given that both heritage managers and community leaders identify this rupture between heritage and local residents, where do they find solutions? Notably, many members of the heritage sector tend toward technocratic responses. A museum professional argued that heritage management should be improved by formally registering heritage, followed by reaching out to educate local communities to "understand the importance of conserving, preserving and protecting their heritage." Others called for increased skills-based training; funding; guidelines; coordination between local governments; identification and listing of heritage; outreach and education to raise awareness; and team building - in short, a whole range of technical or bureaucratic interventions. These suggestions shared a reliance on the existing structures of heritage management and an emphasis on increasing the capacity of the sector to carry out and advance its existing priorities and abilities.

However, from leaders of CBTEs (i.e., local business owners) and local community leaders came a somewhat different idea. This was an emphasis on "ownership," a term which indicated a shift toward collaborative engagement with local communities, but which could also be framed as a technical intervention. One CBTE director suggested that "Engagement has to come in form of partnerships, collaborations to create ownership," while another said that "All that is needed by government is to decentralize the planning process, build trust and let the ownership begin with the technicians in heritage and tourism and we the local community come next." Ownership was a "mindset"18 which would determine that communities could be "involved in the [management] process from start [to] end." 19

And local leaders echoed this framework of ownership as a mindset, viewing it as key to establishing a link between communities and heritage resources. "Ownership starts in the mind ... until we satisfy our minds, heritage resources will always be neglected by us," they said. This perspective was echoed by a CBTE director, who suggested that this ownership mindset would make Nyanza residents "feel motivated to protect these heritage resources." But if heritage was to be protected by communities, it would require a shift in how management was practiced. "We cannot own what we do not understand," stated the local leaders; "we cannot own [anything] when we are not part of the entire process of management and planning." This would, they suggested, counteract the rupture between communities and heritage, enabling them to benefit from it socially and economically. But it would require a shift in practice toward active collaboration and encouragement of local responsibility for heritage resources. This ownership perspective and the changes in 
practice that it required could be summed up: "All in all, we need to be trusted with a sense of responsibility in the management of our heritage."

\section{Discussion}

The findings of our research are effectively two-pronged. First, there is a general sense of the value of heritage, both in its social roles (the inculcation of national pride and establishment of a cohesive identity, which are linked to establishing a secure, post-conflict Rwanda) and in its potential to contribute to material benefit, for example, through development if carefully managed. Second, there is a simultaneous, broadly acknowledged failure of management to connect heritage and its possible benefits to local residents. Solutions to this challenge tend to align along two axes: heritage-sector professionals focus on improving technical capacity while community leaders and local business owners highlight the need to establish an "ownership mindset" wherein communities have a more proprietary relationship with heritage.

The widespread acceptance among our respondents of the idea that heritage plays an important social role aligns with research findings on how the Rwandan government and heritage sector stress the importance of heritage to the construction of a new, peaceful, and unified post-Genocide society (Bolin, 2019a, 2019b; De Becker, 2016; Giblin, 2013). On the other hand, our findings about the sometimes-conflicting views on the relationship between heritage and development are relatively new in Rwandan heritage studies. While other work has shown the challenges which development's modernizing aesthetics pose for the preservation of heritage (Bolin 2020), we largely lack information on how Rwandans themselves envision the relationship between heritage and development. Many of our respondents emphasized the material economic benefits that can come about through heritage development, especially via tourism (to which we might add the potential of development projects to employ heritage sector professionals, like archaeologists, and fund preservation work). Concerns about the effect of such development on heritage conservation and authenticity are fewer, but they do exist.

Almost all interviewees who commented on the relationship between local communities and the heritage management system agreed that there is a gap between the two. We suggest that this situation likely originates from some of the same sources as have been identified in other African cases (e.g., Chirikure et al., 2010; Chirikure et al., 2017; Ndoro and Wijesuriya, 2015). These especially include the legacy of colonialism, which through mechanisms such as missionization and the so-called civilizing mission sought to separate Rwandans from their traditional culture. In the post-independence era, too, people were encouraged to destroy heritage relating to the monarchical past, such as cutting down trees which indicated locations of former royal capitals and royal burials (M. Mugabowagahunde, pers. comm., 2021), further exacerbating this gap.

This distance was made even wider by the significant continuity between colonial and post-colonial heritage management practices, as noted across the continent (Chirikure et al., 2017: 8-9). The form of heritage management most dominant in the 20th century sought to protect heritage from citizens rather than encouraging connections between the two; Rwanda's colonial-era heritage protection law fit squarely into this tradition. 
Although the state's priorities in this area have begun to shift, as outlined in our discussion of Rwanda's heritage sector, the relationship between communities and heritage resources has not yet significantly changed. It is not surprising that the ultimate result is a widely recognized community alienation.

Our interlocutors' suggested solutions to the problems they identify are drawn, we argue, from two parallel genealogies. Many heritage-sector professionals called for technical changes in policy and practice, suggesting skills training, capacity-building, funding increases, etc. The Rwandan government's technocratic capacity-its ability to design and carry out effective interventions and to do so while maintaining accountability and low levels of corruption - has long been recognized, even by critics of the country's political governance (Reyntjens, 2013). It is not surprising, then, that state professionals would situate their proposed solutions in the framework that guides much of the state's efforts and which has proven effective in the past. These professionals' comments also resonated with our understanding of the heritage sector on the national level, where some desire the technical response of decentralization - to echo other decentralizing projects in Rwandan governance (Chemouni, 2014) — in order to better carry out their work. The over-centralization of the heritage sector in Kigali may be another source of the disconnect between heritage and local communities. Notably, many Rwandans working in the heritage sector hold qualifications from outside the country, such as from the United Kingdom. This background would have familiarized them with, for example, the Authorized Heritage Discourse (AHD), which privileges expert disciplinary knowledge and intervention (Smith, 2012). However, there is also a deliberate movement toward decolonization and altering heritage practice in the Rwandan heritage sector (as we outline above), rather than simply replicating the AHD. As a result, these factors are intersecting at a moment of negotiation.

The second genealogy is the language of homegrown solutions and ownership. This appears, first, in the statements of several of our interviewees that heritage can be a useful source of guidance for Rwanda's development: the making of the country's future. Their responses echo calls for "homegrown solutions" which will help to provide a blueprint for culturally appropriate and effective forms of progress. The idea of homegrown solutions is entangled with the higher-order abstractions which shape the country's governing interventions, such as kwigira and agaciro: concepts of self-reliance, dignity, and selfworth. The pursuit of self-reliance and its manifestation through endeavors such as homegrown solutions are enshrined in the Constitution (Article 11), which calls upon the country to make recourse to Rwandan culture and particularly the country's pre-colonial past in order to find Rwandan answers to Rwandan challenges (Gatwa and Mbonyinkebe, 2019a, 2019b; Republic of Rwanda, 2017). In addition to revitalizing Rwandan traditional culture, this is also meant to help reduce reliance on external intervention, including on aid (Beloff, 2020). Specific programs include well-known efforts such as umuganda (community work days) and the famed gacaca courts, which tried the vast majority of Genocide-related cases after 1994. These tactics are sourced from contemporary interpretations of pre-colonial history and cultural values, and one of the national museums - the Kwigira Museum - is dedicated to them and to their origins in the Rwandan past. Moreover, in the context of Rwanda's pursuit of development as a method for ensuring 
independence from foreign influence, self-reliance takes on an economic cast. This too is a goal to which heritage development can contribute.

Local leaders' and CBTE directors' solutions further intersect with these ideals of selfreliance and dignity by calling for "ownership" of heritage and its development. Replacing passivity, dependency, and alienation, an ownership "mindset" is a mode of establishing self-reliance and dignity in heritage. In this framework, the intensive connectivity of ownership - active management and deep engagement - ensures that communities will both care for and profit by the development of heritage resources where they live. These interlocutors suggest that a sense of ownership leads to pride in one's heritage and engagement with it. This further pushes toward involvement in planning processes and opportunities for investment around the site.

As an idea, this echoes priorities which have become increasingly dominant within heritage and archaeological scholarship itself, highlighting - as outlined earlier in this paper - the importance of community engagement, participation, and responsibility for meaningful and ethical heritage management (Atalay, 2012; Colwell and Ferguson, 2008). In the Rwandan case, however, this "ownership" language descends from a genealogy more entangled with domestic priorities of self-reliance and homegrown solutions. Civic education programs (Itorero) run by the national government educate Rwandans, including local leaders, on these concepts of self-reliance and finding Rwandan solutions to Rwandan problems, along with other "vision [s] for the Rwandan state and nationhood" (Sundberg, 2016: 3). As a result, this discourse becomes available for local leaders to deploy. Here, they draw upon the ideals of agaciro and kwigira in order to name and call attention to the state heritage sector's failures in its own language. In so doing, they are attempting to mobilize the sector to live up to the state's own goals, and using the state's own terms to push for more power at the local level.

Finally, we note certain limitations of the study. First, our research focuses on tangible cultural heritage resources, especially sites, which may miss a different set of responses regarding engagement with and management of intangible heritage. Second, we interviewed local leaders as representatives of local communities. As outlined in the methodology section, local leaders' closeness to the communities they represent makes them appropriate proxies for community opinion. However, there may still be a gap between leadership and communities, so this reliance on representative respondents remains a limitation. Further investigation is needed to identify the ways in which leaders' responses may or may not diverge from those of the communities they represent.

\section{Conclusion}

Our research in Nyanza District provides evidence that stakeholders believe in the social and economic value of heritage but, simultaneously, recognize a failure to maximize this value due to a gap between communities and heritage resources. This gap has led to a conflictual relationship between local residents and heritage: for example, some area farmers sought to destroy signage marking the district's cultural trails in 2020, fearing that the development of these trails would threaten their land ownership. ${ }^{20}$ Such tensions are heightened by Rwanda's dense population and land scarcity, which puts intense pressures 
on the survival of heritage resources as well as on heritage development itself (see also Giblin et al., 2011). The situation in Nyanza District is not unlike other contexts of community alienation from heritage, where the "lack of community engagement in heritage management and the interventionism of public authorities generally carry the seeds of conflicts" (Thiaw and Ly, 2020: 73).

What is unusual about the Rwandan context is the presence of governing priorities which, if appropriately leveraged, could facilitate a transformation in heritage management practice: specifically, agaciro and kwigira self-reliance and the development of homegrown solutions. These ideals of governance are fertile ground for a transformation of the district's heritage management in ways that align with both local desires for increased engagement with heritage, and with the decolonizing, community-responsive models for which some heritage scholars have argued. In these models, local communities are substantively consulted, actively collaborate, or even have actual responsibility for heritage management itself (see Colwell and Ferguson, 2008 and Atalay, 2012, among others). Sometimes alongside heritage professionals, communities take on varying levels of responsibility for a given site. This brings communities into decision-making about the uses of the site itself, as well as into receiving and directing benefits from the site. Our research shows that the appetite for such a management model, couched in terms which are locally and nationally meaningful, already exists in Nyanza.

In response, Nyanza District could shift away from centralized government institutions bearing full responsibility for its heritage sites and move instead toward a model that incorporates significant consultation or collaboration. This would bring communities into processes of heritage resource identification, planning for use and development, management and utilization for tourism purposes, outreach to local residents, and directing benefits, including profits and job creation. Such a model would satisfy the local wish for "ownership" of heritage in the district, which is a term used to denote (more than literal legal ownership) a "mindset" of participation and engagement. It would further channel heritage's social and economic benefits toward these communities, while simultaneously helping to protect sites by ensuring that local residents find them valuable and worthy of protection. Moreover, this would contribute to fulfilling the Rwandan state's goal of relying on homegrown solutions to build a future free of colonial influences and dependencies, including those still visible in heritage management and in the country's economic dependence on foreign aid. Such a shift in heritage management in Nyanza District could help to drive changes in the heritage sector more broadly by providing a model which also aligns with the national priorities of pursuing development, decolonization, and self-reliance.

In Nyanza District, it is local leaders' "ownership" language, derived from the state's own discourses, that indicates the levers which could be pushed to achieve these goals. For those interested in issues of community engagement in heritage in the context of decolonization and development, implementation can be challenging. Locating the ways in which new management models can align with other governing priorities is a promising solution, especially in countries like Rwanda which are characterized by strong state involvement in heritage. Here, the Nyanza case speaks to where the sparks for transformation can be found: in local agency and ideation. 


\section{Acknowledgements}

We are grateful to our interlocutors in Nyanza District for speaking with us and sharing their perspectives. We thank Maurice Mugabowagahunde, Maya Ishizawa, and John Giblin, as well as three anonymous reviewers, for their comments on drafts of this article. Thank you to Martin Karenzi and Jean Paul Mugwaneza for permission to use their photos, and to Cornelius Holtorf for comments on the article as well as supporting our field research through the UNESCO Chair on Heritage Futures at Linnaeus University.

\section{Declaration of conflicting interests}

The author(s) declared no potential conflicts of interest with respect to the research, authorship, and/ or publication of this article.

\section{Funding}

The author(s) disclosed receipt of the following financial support for the research, authorship, and/or publication of this article: This is research project supported by Linnéuniversitetet.

\section{Notes}

1. One of the authors of this article (Nkusi) is an employee since 2012 of INMR and now RCHA, where he has been a Historical Sites Protection Officer and Heritage Sites Protection Specialist. His work has involved numerous heritage management projects in Rwanda, including countrywide field surveys to identify and document sites of outstanding value. In Nyanza District, since 2018, he has worked on heritage site branding as well as partnerships between INMR and Rwanda Development Board (RDB), the German cooperation agency GIZ, and others. Between 2013 and 2018, the other author (Bolin) conducted a cumulative year and a half of ethnographic fieldwork in Rwanda for her doctoral dissertation on the uses of heritage in post-Genocide Rwanda (Bolin, 2019a), focused in part on heritage conservation and development, and undertaken under the auspices of INMR. Subsequently, she has studied the international aspects of Rwandan heritage through research on repatriation from Germany to Rwanda in 2019-2022.

2. See http://invest.nyanza.gov.rw (accessed 21 January 2021) and National Institute of Statistics of Rwanda, 2012.

3. The demographic and statistical data in this paragraph from National Institute of Statistics of Rwanda, 2012, 2016 are the most recent published figures at the Nyanza District level. Numbers from 2016-17 are similar, with 46.5\% living in poverty according to Nyanza District Public Relations and Communication Officer Patrick Mfura (pers. comm., 2021).

4. Nyanza District authority.

5. Student.

6. CBTE director.

7. Notably, genocidal violence in Rwanda proceeded along what are usually described as ethnic lines, but as Mamdani (2001) notes, these identities had become (relatively recently) racialized. The heritage that the Rwandan government emphasizes today is not understood to be distinguished between Hutu, Tutsi, or Twa groups, but rather to be a common heritage of all, predating the racialization of identity that enabled the Genocide. 
8. CBTE director.

9. Museum professional.

10. Museum professional.

11. Museum professional.

12. CBTE director.

13. Museum professional.

14. Museum professional.

15. Museum professional.

16. CBTE director.

17. Expert consultant.

18. Local community leaders; CBTE director.

19. Local community leaders.

20. While community members were meant to have been consulted in advance of installation by a joint team involving GIZ/Eco-Emploi and RCHA, outside consultants' schedules meant that signage was installed first and community consultation proceeded afterwards. In light of the reaction in this case, GIZ and its partners' current projects in Nyanza focus on increasing community engagement through mechanisms such as identifying tourism projects that involve the community and training community members to run tourism businesses.

\section{References}

Atalay S (2006) Indigenous archaeology as decolonizing practice. American Indian Quarterly 30(3/ 4): $280-310$.

Atalay S (2012) Community-Based Archaeology: Research with, by, and for Indigenous and Local Communities. Berkeley: University of California Press.

Baillie B and Sørensen MLS (eds) (2021a) African Heritage Challenges: Communities and Sustainable Development. Singapore: Palgrave Macmillan.

Baillie B and Sørensen MLS (2021b) Heritage challenges in Africa: Contestations and expectations. In: Baillie B and Sørensen MLS (eds) African Heritage Challenges: Communities and Sustainable Development. Singapore: Palgrave Macmillan, pp. 1-43.

Beloff JR (2020) Foreign Policy in Post-Genocide Rwanda: Elite Perceptions of Global Engagement. Milton Park: Routledge.

Bolin A (2019a) A Country without Culture Is Destroyed: Making Rwanda and Rwandans Through Heritage. PhD Thesis. USA: Stanford University.

Bolin A (2019b) Dignity in death and life: Negotiating agaciro for the nation in preservation practice at Nyamata Genocide Memorial, Rwanda. Anthropological Quarterly 92(2): 345-374.

Bolin A (2020) Imagining genocide heritage: Material modes of development and preservation in Rwanda. Journal of Material Culture 25(2): 196-219.

Brosius JP, Tsing AL and Zerner C (eds) (2005) Communities and Conservation: Histories and Politics of Community-Based Natural Resource Management. Walnut Creek, CA: AltaMira Press.

Byanafashe D and Rutayisire P (eds) (2016) History of Rwanda: From the Beginning to the End of the Twentieth Century. Kigali: National Unity and Reconciliation Commission. 
Chemouni B (2014) Explaining the design of the Rwandan decentralization: Elite vulnerability and the territorial repartition of power. Journal of Eastern African Studies 8(2): 246-262.

Chirikure S (2021) Great Zimbabwe: Reclaiming a "Confiscated" Past. London and New York: Routledge.

Chirikure S, Manyanga M, Ndoro W, et al. (2010) Unfulfilled promises? Heritage management and community participation at some of Africa's cultural heritage sites. International Journal of Heritage Studies 16(1-2): 30-44.

Chirikure S, Ndoro W and Deacon J (2017) Approaches and trends in African heritage management and conservation. In: Ndoro W, Chirikure S and Deacon J (eds) Managing Heritage in Africa: Who Cares? London and New York: Routledge/Taylor \& Francis Group, pp. 1-21.

Chitty G (ed) (2017) Heritage, Conservation and Community: Engagement, Participation and Capacity Building. New York: Routledge.

Colwell C and Ferguson TJ (eds) (2008) Collaboration in Archaeological Practice: Engaging Descendant Communities. Lanham, MD: AltaMira Press.

Colwell C and Joy C (2015) Communities and ethics in the heritage debates. In: Meskell L (ed) Global Heritage: A Reader. Chichester and Malden, MA: John Wiley \& Sons, pp. 112-130.

Comer DC (2012) Tourism and Archaeological Heritage Management at Petra: Driver to Development or Destruction? New York: Springer.

De Becker L (2016) Imagining the post-colonial and post-genocidal nation in the National Museum of Rwanda, Butare. Critical Interventions 10(3): 293-308.

Des Forges AL (2011) Defeat Is the Only Bad News: Rwanda Under Musinga, 1896-1931. Madison: The University of Wisconsin Press.

Gatete C (2016) The Rwanda we want: Towards 'Vision 2050'. PowerPoint presentation presented at the Umushyikirano (National Dialogue), Rwanda, 16 December.

Gatwa T and Mbonyinkebe D (eds) (2019a) Home-Grown Solutions: Legacy to Generations in Africa: Drawing Resources from the Rwandan Way of Life. Geneva: Globethics.net, Vol. 1.

Gatwa T and Mbonyinkebe D (eds) (2019b) Home-Grown Solutions: Legacy to Generations in Africa: Memory and Reconciliation. Language, Culture and Development. Geneva: Globethics.net, Vol. 2.

Giblin J (2012) Decolonial challenges and post-genocide archaeological politics in Rwanda. Public Archaeology 11(3): 123-143.

Giblin J (2013) Post-conflict heritage: Symbolic healing and cultural renewal. International Journal of Heritage Studies 20(5): 1-19.

Giblin J (2018) Heritage and the use of the past in East Africa. In: Spear T (ed) Oxford Research Encyclopedia of African History. Oxford: Oxford University Press. DOI: 10.1093/acrefore/ 9780190277734.013.135.

Giblin J, Humphris J, Mugabowagahunde M, et al. (2011) Challenges for pre-colonial archaeological site management in Rwanda. Conservation and Management of Archaeological Sites 13(2-3): 174-188.

Giblin J, Mugabowagahunde M and Ntagwabira A (2017) International heritage tourism in Rwanda: Paving over the past at the Musanze Caves. Conservation and Management of Archaeological Sites 19(2): 126-140.

Gitera V (2008) The Development and Promotion of Heritage Tourism in Rwanda. MTech Thesis, Cape Peninsula University of Technology, South Africa. 
Gould PG (2018) Empowering Communities Through Archaeology and Heritage: The Role of Local Governance in Economic Development. London: Bloomsbury Publishing PLC.

Gould PG and Pyburn KA (eds) (2017). Collision or Collaboration: Archaeology Encounters Economic Development. Cham: Springer.

Government of Rwanda (1939) Protection des Sites, Monuments, et Productions de l'Art Indigène. Kigali: Government of Rwanda.

Government of Rwanda (2016) Law No. 28/2016 of 22/7/2016 on the Preservation of Cultural Heritage and Traditional Knowledge. Kigali: Government of Rwanda.

Hasselskog M (2018) Rwandan 'home grown initiatives': Illustrating inherent contradictions of the democratic developmental state. Development Policy Review 36(3): 309-328.

Herrera A (2014) Commodifying the indigenous in the name of development: The hybridity of heritage in the twenty-first-century Andes. Public Archaeology 13(1-3): 71-84.

Hicks D (2020) The Brutish Museums: The Benin Bronzes, Colonial Violence and Cultural Restitution. London: Pluto Press.

Higgins V and Douglas D (eds) (2020). Communities and Cultural Heritage: Global Issues, Local Value. London and New York: Routledge/Taylor \& Francis Group.

Ishizawa M and Karangwa J (2021) The interpretive reconstruction of the royal capital in Nyanza, Rwanda. In: ICOMOS and ICCROM (eds) Analysis of Case Studies in Recovery and Reconstruction. Paris and Sharjah: ICOMOS and ICCROM, Case studies Vol. 2, pp. 60-89.

Jessee E (2017) Negotiating Genocide in Rwanda: The Politics of History. London: Palgrave Macmillan.

Jopela APJ (2011) Traditional custodianship: A useful framework for heritage management in southern Africa? Conservation and Management of Archaeological Sites 13(2-3): 103-122.

Joseph M (2002) Against the Romance of Community. Minneapolis: University of Minnesota Press.

Kamuzinzi PK, Shukla J and Ndabaga E (2015) The effectiveness of Rwanda Development Board tourism revenue sharing program towards local community socioeconomic development: A case study of Nyungwe National Park. European Journal of Hospitality and Tourism Research 3(2): 47-63.

Keitumetse S (2016) African Cultural Heritage Conservation and Management: Theory and Practice from Southern Africa. Cham: Springer.

Kyriakidis E (2019) A Community Empowerment Approach to Heritage Management: From Values Assessment to Local Engagement. Abingdon and New York: Routledge.

Lafrenz Samuels K (2010) Material heritage and poverty reduction. In: Labadi S and Long C (eds) Heritage and Globalisation. London and New York: Routledge, pp. 202-217.

Lane PJ (2011) Future urban growth and archaeological heritage management: Some implications for research activity in Africa. Conservation and Management of Archaeological Sites 13(23): $134-159$.

Makuvaza S (ed) (2014) The Management of Cultural World Heritage Sites and Development in Africa: History, Nomination Processes and Representation on the World Heritage List. New York: Springer.

Mamdani M (2001) When Victims Become Killers: Colonialism, Nativism, and the Genocide in Rwanda. Princeton, NJ: Princeton University Press.

Mann L and Berry M (2015) Understanding the political motivations that shape Rwanda's emergent developmental state. New Political Economy 21(1): 119-144. 
Meskell L (2010) Human rights and heritage ethics. Anthropological Quarterly 83(4): 839-859. Ministry of Finance and Economic Planning (2017) 7 Years Government Programme: National Strategy for Transformation (NST1) 2017-2024. Kigali: Government of Rwanda. Available at: https://www.nirda.gov.rw/uploads/tx_dce/National_Strategy_For_Trsansformation_-NST1-min. pdf (accessed 27 September 2021).

Ministry of Sports and Culture (2008) Policy on Cultural Heritage. Kigali: Government of Rwanda.

Ministry of Sports and Culture (2015) National Culture Heritage Policy. Kigali: Government of Rwanda.

Ministry of Sports and Culture (2016) Five Year Strategic Plan for the Development of Cultural Tourism 2017-2022. Kigali: Ministry of Sports and Culture. Available at: http://www.minispoc.gov.rw/ fileadmin/document_2019/FIVE_YEAR_STRATEGIC_PLAN_FOR_THE_DEVELOPMENT_ OF_CULTURAL_TOURISM_2017-2022.pdf (accessed 27 September 2021).

Munanura IE, Backman KF, Hallo JC, et al. (2016) Perceptions of tourism revenue sharing impacts on Volcanoes National Park, Rwanda: A sustainable livelihoods framework. Journal of Sustainable Tourism 24(12): 1-18.

National Institute of Statistics of Rwanda (2012) EICV3 district profile - South - Nyanza. Kigali: Republic of Rwanda. Available at: http://www.statistics.gov.rw/publication/eicv-3-nyanzadistrict-profile (accessed 27 September 2021).

National Institute of Statistics of Rwanda (2016) Demographic and Health Survey RDHS 2014-15: District Profile Chart Book: Southern Province. Kigali: Republic of Rwanda. Available at: http://www.statistics. gov.rw/publication/demographic-and-health-survey-20142015-southern-province-profile (accessed 27 September 2021).

Ndlovu N (2017) Bridging the divide: Heritage management and development in the twenty-first century. In: Gould PG and Pyburn KA (eds) Collision or Collaboration: Archaeology Encounters Economic Development. Cham: Springer, pp. 103-116.

Ndoro W, Chirikure S and Deacon J (eds) (2017) Managing Heritage in Africa: Who Cares? London and New York: Routledge/Taylor \& Francis Group.

Ndoro W and Wijesuriya G (2015) Heritage management and conservation: From colonization to globalization. In: Meskell L (ed) Global Heritage: A Reader. Chichester and Malden, MA: John Wiley \& Sons, 131-149.

Republic of Rwanda (2017) Governance and home grown solutions. Available at: https://www.gov. rw/highlights/governance (accessed 27 September 2021).

Reyntjens F (2013) Political Governance in Post-Genocide Rwanda. New York: Cambridge University Press.

Rodney W (2018) How Europe Underdeveloped Africa. Brooklyn: Verso.

Schmidt PR and Pikirayi I (eds) (2016) Community Archaeology and Heritage in Africa: Decolonizing Practice. London and New York: Routledge.

Simpson F (2008) Community archaeology under scrutiny. Conservation and Management of Archaeological Sites 10(1): 3-16.

Smith L (2012) Discourses of heritage: Implications for archaeological community practice. Nuevo Mundo Mundos Nuevos. DOI: 10.4000/nuevomundo.64148 (accessed 7 September 2021).

Sundberg M (2016) Training for Model Citizenship: An Ethnography of Civic Education and StateMaking in Rwanda. London: Palgrave Macmillan. 
The Council of Europe (2013) The Role of Culture and Cultural Heritage in Conflict Prevention, Transformation, Resolution and Postconflict Action: The Council of Europe Approach. Strasbourg: The Council of Europe. Available at: https://edoc.coe.int/en/european-cultural-convention/5785-therole-of-culture-and-cultural-heritage-in-conflict-prevention-transformation-resolution-and-postconflictaction-the-council-of-europe-approach.html (accessed 27 September 2021).

Thiaw I and Ly MA (2020) Heritage management, community engagement and resilience in Senegal. In: Higgins V and Douglas D (eds) Communities and Cultural Heritage: Global Issues, Local Value. London and New York: Routledge/Taylor \& Francis Group, pp. 67-77. Umuhoza C (2021) Ethnographic Museum of Rwanda. Presentation given at the Fowler Museum, University of California-Los Angeles, 23 March.

\section{Author biographies}

Annalisa Bolin is a Postdoctoral Fellow in the UNESCO Chair on Heritage Futures, Linnaeus University, Sweden. She holds a $\mathrm{PhD}$ in Anthropology from Stanford University. Her research focuses on the uses of heritage in post-Genocide Rwanda, with attention to politics, development, memorialization, and international relationships, including repatriation from Germany to Rwanda.

David Nkusi is a heritage studies and management expert. He received his master's degree in heritage management from the University of Kent and Athens University of Economics and Business and is currently a Heritage Sites Protection Specialist at RCHA. He has undergone professional, accredited trainings by Heritage Management Organization, Greece and worked on Rwandan heritage projects supported by Linnaeus University, the German cooperation agency GIZ, Rwanda Development Board, MasterCard Foundation, Howarth HTL, and Senior Expert Services from Germany. He is a member of the International Institute for Conservation. His work involves research and publication, Training of Trainers, and coordination of key stakeholders in the heritage and tourism industry in Rwanda and beyond. 